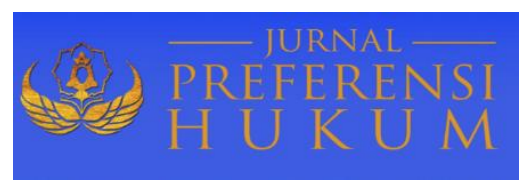

Jurnal Preferensi Hukum | ISSN: XXXX | E-ISSN: XXXX

Vol. 1 No. 1 - Juli 2020 hal. 91-96| Available online at

https://www.ejournal.warmadewa.ac.id/index.php/juprehum

\title{
PENGATURAN SANKSI KUMULATIF DALAM TINDAK PIDANA KORUPSI
}

\author{
I Made Sandi Cahyadi, I Nyoman Putu Budiartha, I Made Minggu Widyantara \\ Fakultas Hukum Universitas Warmadewa, Denpasar - Bali, Indonesia
}

\begin{abstract}
Abstrak
Tindak pidana korupsi adalah suatu kejahatan terhadap hak sosial dan hak ekonomi masyarakat. Tindak pidana korupsi sudah menjadi suatu perbuatan atau kejahatan yang luar biasa. Begitu juga dalam usaha pemberantasannya tidak lagi bisa dilakukan dengan cara yang biasa, tetapi harus menggunakan cara yang luar biasa. Tindak pidana korupsi adalah suatu perbutan jahat yang bisa membuat negara menjadi rugi. Di Indonesia tindak pidana korupsi sudah meluas didalam masyarakat, perkembangannya terus meningkat dari tahun ke tahun. Penelitian ini bertujuan untuk menganalisis pengaturan sanksi kumulatif dalam tindak pidana korupsi dan menganalisis pertimbangan hakim dalam menjatuhkan sanksi pidana kurungan pengganti denda sebagai salah satu sanksi kumulatif dalam tindak pidana korupsi. Penelitian yang digunakan adalah penelitian hukum normatif dengan menggunakan pendekatan perundangundangan, pendekatan konseptual, pendekatan kasus yang kemudian dianalisis secara deskriptif. Berdasarkan hasil pembahasan dapat dijelaskan bahwa pengaturan sanksi kumulatif dalam tindak pidana korupsi diatur dalam pasal 2 , pasal 6, pasal 8, pasal 9, pasal 10, pasal, 12, pasal 12B. Pertimbangan hakim dalam menjatuhkan putusan yaitu pertimbangan secara yuridis dan melihat fakta-fakta hukum yang terungkap dalam persidangan. Jadi dapat disimpulkan pendekatan yang dipergunakan oleh hakim dalam pertimbangan penjatuhan putusan adalah teori keseimbangan, teori pendekatan seni dan intuisi, teori pendekatan keilmuan, teori pendekatan pengalaman dan teori ratio decidendi.
\end{abstract}

Kata Kunci: Denda; Sanksi Kumulatif; Tindak Pidana Korupsi

\begin{abstract}
Corruption is a crime against social and economic rights of the community. Corruption has become an extraordinary crime or crime. Likewise, the eradication effort can no longer be done in the usual way, but must use extraordinary methods. Corruption is an evil act that can make the country a loss. In Indonesia, corruption has been widespread in society, its development continues to increase from year to year. This study aims to analyze the regulation of cumulative sanctions in corruption and analyze the judges' consideration in imposing criminal sanctions in place of fines as one of the cumulative sanctions in corruption. The research used was normative legal research using a statutory approach, conceptual approach, case approach which was then analyzed descriptively. Based on the results of the discussion it can be explained that the regulation of cumulative sanctions in corruption is regulated in article 2 , article 6, article 8, article 9, article 10, article, 12, article 12B. Judge's consideration in giving a ruling is judicial consideration and seeing the legal facts revealed in the trial. So it can be concluded that the approach used by the judge in consideration of the decision is the balance theory, the theory of the art approach and intuition, the scientific approach theory, the experience approach theory and the ratio decidendi theory.
\end{abstract}

Keywords: Cumulative Sanctions; Corruption; Fine

\section{PENDAHULUAN}

Proses pembangunan dalam suatu negara dapat menjadikan suatu negara itu menjadi maju dari segi kehidupan ataupun dari segi keuangan dalam masyarakat, disamping itu dapat juga mengakibatkan perubahan dari segi sosial dalam kehidupan masyarakat yang mempunyai dampak sosial yang kurang baik, terutama yang ada kaitannya dengan masalah tindak pidana yang bisa meresahkan masyarakat yang terus berkembang dari tahun ke tahun. Suatu contoh tindak pidana yang bisa diklasifikasikan cukup membuat 
resah warga yaitu tindak pidana korupsi. Tindak pidana ini tidak hanya dapat merugikan kekayaan atau aset negara, tetapi juga merupakan salah satu kejahatan terhadap hak sosial dan ekonomi masyarakat.

Korupsi merupakan suatu perbuatan orang yang dilakukan dengan menyalahgunakan kewenangan atau kekuasaan untuk kepentingan diri sendiri atau sebuah kelompok sehingga dapat membuat negara menjadi rugi karena perbuatannya. Ada juga yang berpendapat bahwa korupsi adalah suatu kebusukan, perbuatan yang tidak jujur yang menyimpang dari perbuatan baik. Korupsi jelas telah membuat rusak mental para pejabat dengan melakukan suatu perbuatan suap menyuap, dan terdapat ketidakjujuran dalam berkompetisi, dikatakan juga sebagai suatu pelanggaran terhadap kepercayaan. Tindak pidana korupsi dikatakan sebagai kejahatan kerah putih, karena kejahatan ini dominan dilakukan oleh orang-orang yang memiliki kemampuan intelektual yang bagus, orang yang memiliki wewenang dan atau kekuasaan. Kejahatan korupsi sangat sulit diungkap karena kejahatan ini merupakan suatu kejahatan yang terorganisasi atau kejahatan yang dilakukan oleh lebih dari satu orang.

Tindak pidana korupsi adalah suatu tindakan yang bisa membuat suatu negara menjadi rugi baik dari segi keuangan, pendidikan bahkan dari segi kesehatan, oleh karenanya pemberantasan korupsi harus dilakukan dengan bersungguh-sungguh dengan memberikan sanksi yang seberat-beratnya kepada orang yang melakukan korupsi agar membuat orang tersebut menjadi jera dan tidak melakukan korupsi lagi (Kristian \& Gunawan, 2015)

Pemberantasan korupsi secara hukum didalam hukum positif Indonesia yaitu dengan menerapkan atau diberlakukannya secara tegas dan jelas Undang-Undang tentang Pemberantasan Tindak Pidana Korupsi dan berbagai ketentuan terkait yang bersifat tegas. Undang-Undang yang dimaksud adalah Undang-Undang Nomor 31 Tahun 1999 sebagaimana telah diubah oleh UU No. 20 Tahun 2001 tentang Pemberantasan Tindak Pidana Korupsi (Arsyad, 2013).

Pada tahun 2002 negara Indonesia mendirikan sebuah Lembaga Negara yaitu Komisi Pemberantasan Korupsi (KPK), Lembaga ini dibentuk dengan tujuan meningkatkan upaya dalam pemberantasan tindak pidana korupsi. KPK bersifat independent dan bebas dari pengaruh kekuasaan manapun dalam melaksanakan tugas dan wewenangnya. KPK didirikan berdasarkan UU NRI No. 30 Tahun 2002 tentang Komisi Pemberantasan Tindak Pidana Korupsi.

Perkembangan pemberantasan korupsi saat ini telah difokuskan pada tiga isu pokok, yaitu pencegahan korupsi, pemberantasan korupsi, dan pengembalian aset hasil korupsi. Pengembalian kerugian atau pengembalian aset hasil dari korupsi yang dilakukan oleh seseorang akan membantu memulihkan kerugian yang dialami negara disamping itu juga akan membuat pelaku tidak bisa menikmati hasil perbuatan korupsi tersebut. Hal ini juga dapat dilakukan dengan menyita atau mengambil secara paksa barang- barang tertentu yang didapatkan dan dihasilkan dari suatu perbuatan pidana, sebagai suatu hukuman tambahan disamping hukuman pokok seperti penjara atau denda yang terdapat dalam Kitab Undang-undang Hukum Pidana (KUHP). Dalam tindak pidana korupsi dua sanksi pokok dapat dijatuhkan oleh hakim dalam amar putusannya yang dikenal dengan perumusan sanksi secara kumulatif.

Denda adalah sanksi yang terdapat dalam kasus tindak pidana korupsi yang merupakan sanksi pidana pokok yang dapat dikenakan terhadap orang yang melakukan tindak pidana korupsi. Denda merupakan suatu bentuk hukuman berupa kewajiban dari terdakwa untuk membayarankan sejumlah uang sebagai tebusan atas perbuatan yang telah ia lakukan. Ada dua jenis sanksi pidana denda dalam hukum yaitu, sanksi denda yang menjadi sanksi pidana dan denda yang menjadi sanksi administratif. Tujuannya sama yaitu sama-sama untuk membuat jera orang yang melakukan perbuatan jahat seperti melakukan korupsi, yang membedakan yaitu proses atau cara sehingga denda itu dijatuhkan kepada seseorang, dan terhadap siapa sanksi denda tersebut harus dibayarkan, serta bagaimana akibatnya jika denda tersebut tidak dibayarkan oleh pelaku atau terpidana (Mertha, 2014) Dalam tindak pidana korupsi khususnya, didalam amar putusan hakim yang sempat penulis baca, apabila sanksi denda tidak dibayar akan diganti dengan pidana kurungan.

Kurungan pengganti adalah hukuman pokok dalam hukum pidana yang dimana kurungan pengganti hukumannya lebih ringan dari pada hukuman penjara, sanksi kurungan pengganti yaitu sanksi yang bisa dijatuhkan jika pelaku tindak pidana tidak mampu membayar denda yang dijatukan. Lama kurungan pengganti ditentukan oleh seberapa banyak denda yang harus dibayarkan oleh terpidana dalam suatu 
putusan pengadilan. Dalam beberapa penelitian terkait, pertama (Valerian, 2019) menyatakan bahwa Pengaturan pidana denda di Indonesia tidak selalu bersikukuh pada ancaman maksimum dalam rumusan delik tidak hanya mungkin, melainkan telah dianut oleh UU Drt TPE, yang notabene lahir saat Republik Indonesia baru berumur 10 tahun. Selanjutnya, (Haryadi, 2014) mengatakan bahwa strategi kebijakan pemidanaan dalam kejahatan-kejahatan tertentu harus memperhatikan hakikat permasalahannya. Jika hakikat permasalahannya lebih pada masalah perekonomian atau perdagangan maka harus lebih diutamakan sanksi tindakan dan/atau denda. Ketiga, (Bauhr, Charron, \& Wängnerud, 2019) mengatakan bahwa dimasukkannya perempuan dalam dewan lokal sangat negatif terkait dengan prevalensi korupsi kecil dan besar. Namun, pengurangan korupsi terutama dialami di kalangan perempuan.

Namun bagaimanapun, dalam praktiknya, terdapat kontradiktif dalam penjatuhan suatu sanksi pidana kurungan pengganti denda, dimana terdapat ketidaksesuaian antara banyaknya denda dengan lamanya kurungan pengganti yang dijatuhkan. Oleh karenanya terpidana tindak pidana korupsi cenderung lebih memilih sanksi kurungan karena itu dianggap lebih ringan daripada sanksi pidana denda. Disinilah kita perlu mengkaji bagaimana pengaturan sanksi pidana kumulatif dalam tindak pidana korupsi dan bagaimana dasar pertimbangan hakim dalam menjatuhkan sanksi pengganti dalam perumusan amar putusannya. Berdasarkan latar belakang, penelitian ini bertujuan untuk menganalisis Pengaturan Sanksi Kumulatif Dalam Tindak Pidana Korupsi dan menganalisis pertimbangan Hakim Dalam Menjatuhkan Sanksi Pidana Kurungan Pengganti Denda Sebagai Salah Satu Sanksi Kumulatif Dalam Tindak Pidana Korupsi

\section{METODE}

Pendekatan yang digunakan dalam penelitian ini adalah metode penelitian hukum normatif. Penelitian hukum normative yaitu penelitian hukum yang mempelajari bahkan menelaah seluruh hukum tertulis dari semua sumber hukum yang ada. Pendekatan yang digunakan yaitu pendekatan perundangundangan, pendekatan konseptual, dan pendekatan kasus. Teknik yang digunakan untuk mengumpulkan bahan hukum yaitu dengan cara studi kepustakaan: membaca, menelaah dan mencatat semua buku-buku serta peraturan-peraturan yang berkaitan dengan pengaturan sanksi kumulatif dalam tindak pidana korupsi. Kemudian seluruh bahan hukum dianalisis secara deskriptif

\section{HASIL DAN PEMBAHASAN}

\section{Pengaturan Sanksi Kumulatif Dalam Tindak Pidana Korupsi}

Sanksi dapat diartikan sebagai suatu sarana untuk memperkuat suatu aturan atau norma oleh sebab itu harus ditaati dan tidak boleh dilanggar. Dengan menggunakan sanksi dalam sebuah peraturan maka diharapkan dapat terciptanya perarturan hukum yang baik yang memiliki ketegasan, sehingga apa yang termuat didalam aturan atau norma tersebut bisa mendorong seorang untuk tidak melakukan pelanggaran dan menjalani kehidupan sesuai dengan aturan atau norma yang diatur tersebut. Dengan menggunakan sanksi dalam setiap peraturan maka diharapkan sanksi bisa menjadi penguat atau penegas suatu aturan hukum. Dalam perbincangan tentang sanksi, maka biasanya suatu sanksi diberikan kepada orang yang melanggar suatu norma, dengan mempertimbangkan perbuatan yang telah orang terebut lakukan. Kekuatan dalam suatu sanksi diukur dengan seberapa banyak pidana yang diancamkan terhadap orang atau pelanggar. Dengan diterapkannya sanksi bertujuan sebagai alat dalam hal mempertahankan atau membuat jera pelaku dengan ancaman sanksi secara real agar tidak kehilangan kekuatanya untuk mewujudkan suatu keadilan yang hendak ditegakkan.

Sanksi merupakan konsekuensi logis dari suatu perbuatan yang dilakukan oleh seseorang. Sanksi mempunyai pengertian yang sangat luas. Banyak bentuk sanksi dalam hukum, misalnya sanksi moral, sanksi hukum. Sanksi dapat memiliki pengertian yang sama dengan hukuman. Pidana (straf) adalah sanksi yang hanya diberlakukan dalam lapangan hukum pidana. Pengertian sanksi pidana mencangkup seluruh jenis pidana dan tindakan yang sebagaimana diatur dalam hukum pidana, baik sanksi yang diatur didalam Kitab Undang Undang Hukum Pidana atau KUHP maupun yang diatur diluar KUHP.

Berkaitan dengan penjatuhan sanksi pidana dalam hukum pidana, maka hanya satu jenis pidana pokok yang dapat dijatuhkan pada pelaku kejahatan. Dalam KUHP dikenal dengan sistem alternative 
(berbagai jenis pidana pokok yang diancamkan atau didakwakan, namun hanya satu yang bisa dijatuhkan), namun dalam tindak pidana tertentu di luar KUHP di kenal pula sistem kumulatif/ kumulasi (pelaku kejahatan dapat dibebankan 2 sanksi pokok sekaligus).

Sanksi kumulatif dalam tindak pidana korupsi merupakan dua sanksi pokok yang dijatuhkan secara serentak dan mutlak, artinya hakim harus menjatuhkan dua pidana pokok terhadap terdakwa tindak pidana korupsi. Dua pidana pokok yang bisa dijatuhkan menurut Undang-Undang No. 20 Tahun 2001 tentang Pemberantasan Tindak Pidana Korupsi adalah pidana penjara dan pidana denda.

Teori kumulatif adalah teori yang disandarkan pada aktivitas pembentukan undangundang dan aktivitas tersebut memiliki alasan-alasan historis, sosiologis, yuridis dan politis. Kumulatif menurut Kamus Besar Bahasa Indonesia bersangkutan dengan kumulasi yang artinya bersifat menambah; terjadi dari bagian yang makin bertambah; bertumpuk-tumpuk. Definisi kumulatif adalah segala sesuatu yang sifatnya terus bertambah atau menumpuk dari berbagai sisi atau bagian, yang Bahasa latinnya berasal dari kata "Cumulare" (Jurdi, 2019).

Pengertian kumulatif adalah sesuatu yang terus bertambah dari berbagai sisi atau bagian. Sanksi kumulatif merupakan pemberian dua sanksi yang setara dengan sifat menambahkan atau menumpuk, artinya suatu sanksi tersebut dibebankan dan harus dujalankan oleh terdakwa tanpa terkecuali, biasanya sanksi yang sifatnya kumulatif yang dijatuhkan didalam persidangan yaitu sanksi penjara dan denda, orang yang melakukan korupsi misalnya dalam suatu peradilan maka orang itu biasanya dijatuhkan dua sanksi pokok sekaligus yaitu penjara dan denda. Pemberian dua sanksi ini bertujuan untuk membuat orang yang melakukan korupsi jera dan tidak lagi melakukan perbuatan seperti itu. Kumulatif dapat dijumpai dalam tindak pidana khusus saja seperti korupsi dan narkotika, dalam KUHP memang tidak dikenal dengan adanya perumusan kumulasi atau penggabungan dua sanksi pokok, karena sistem atau sifat perumusan sanksi dalam KUHP yaitu dengan sifat alternative bukan kumulatif. Sama seperti yang diungkapkan oleh (Irfani \& Maerani, 2019) bahwa masih ada kelemahan yang terkandung dalam UndangUndang Anti-Korupsi saat ini masih belum kuat, terutama tentang perumusan sanksi pidana minimum, yang tidak merumuskan pedoman hukuman untuk menerapkan ancaman pidana minimum ini.

Sistem sanksi kumulatif dalam undang-undang ditandai dengan ciri khas, yaitu dalam peraturannya terdapat kata hubung "dan" didalam perumusan aturannya. Kata "dan" menurut Kamus Besar Bahasa Indonesia versi online adalah kata hubung satuan Bahasa (kata, frasa, klausa, dan kalimat) yang setara, yang termasuk tipe yang sama serta memiliki fungsi yang tidak berbeda. Sesuai dengan arti kata kumulatif, yakni bersifat menambah, maka kata "dan" adalah kumulatif. Namun berbeda dengan (Aryadi \& Pudyatmoko, 2020), menyatakan dalam penelitiannya bahwa penerapan sanksi kumulatif eksternal berlawanan dengan asas ultimum remedium, karena pengenaan sanksi administrasi bagi terpidana dikenakan setelah yang bersangkutan dikenakan sanksi pidana

Undang-undang tindak pidana korupsi (UU No. 31 Tahun 1999 sebagaimana telah diubah oleh UU No. 20 Tahun 2001 tentang Pemberantasan Tindak Pidana Korupsi) yaitu suatu contoh Undang-undang yang memuat suatu sistem kumulatif. Dengan ciri kata hubung "dan" dalam perumusan beberapa pasalnya, jadi hakim harus memberikan pidana dua sekaligus kepada terdakwa tindak pidana korupsi. Sistem perumusan kumulatif ini tidak dijumpai di dalam KUHP atau dengan kata lain KUHP tidak mengenal adanya kumulasi pidana pokok.

Pengaturan penjatuhan sanksi pidana terhadap pelaku tindak pidana korupsi dengan sistem perumusan kumulatif terdapat dalam beberapa pasal yaitu, pasal 2, pasal 6, pasal 8, pasal 9, pasal 10, pasal 12 dan pasal 12B Undang-Undang Nomor 20 Tahun 2001 tentang Pemberantasan Tindak Pidana Korupsi. Dikatakan sebagai sanksi yang bersifat kumulatif, pasal-pasal tersebut diatas karena dalam bunyi setiap pasal tersebut terdapat kata penghubung "dan" yang merupakan sifat dari kumulatif itu sendiri. Pasal-pasal tersebut diatas dalam pengaturannya setiap ancaman pidananya menggunakan kata penghubung "dan" seperti misalnya dijatuhkan pidana penjara dan pidana denda, artinya kedua pidana tersebut harus dijatuhkan dan dilaksanakan oleh terdakwa.

Sistem imperative kumulatif yaitu penjatuhan dua pidana pokok yang merupakan suatu keharusan yang mutlak. Selain penjatuhan sanksi yang bersifat kumulatif dengan ciri kata hubung "dan”, dalam tindak 
pidana korupsi sistem dua jalur pemidanaan (double track system) hampir sama dengan perumusan kumulatif yaitu sama-sama merupakan sebuah penggabungan pidana atau penimbunan atau pemberatan pidana.

\section{Pertimbangan Hakim Dalam Menjatuhkan Sanksi Pidana Kurungan Pengganti Denda Sebagai Salah Satu Sanksi Kumulatif Dalam Tindak Pidana Korupsi}

Hakim dalam Undang-Undang Pengadilan Tindak Pidana Korupsi terdiri dari Hakim Karier dan Hakim ad hoc. Hakim Karier adalah hakim pada pengadilan negeri, pengadilan tinggi, dan Mahkamah Agung yang ditetapkan sebagai hakim tindak pidana korupsi. Hakim ad hoc merupakan seseorang yang diangkat berdasarkan persyaratan yang ditentukan dalam Undang- Undang Nomor 46 Tahun 2009 tentan Pengadilan Tindak Pidana Korupsi. Keberadaan Hakim ad hoc diperlukan dalam pengadilan tipikor karena keahliannya sejalan dengan kompleksitas perkara tindak pidana korupsi, baik yang menyangkut modus operandi, pembuktian, maupun luasnya cakupan tindak pidana korupsi antara lain dibidang keuangan dan perbankan, perpajakan, pasar modal, pengadaan barang atau jasa pemerintah.

Berkaitan dengan wewenangnya hakim dalam persidangan harus patuh terhadap undang-undang yang mengaturnya, hakim juga harus mempunyai kejujuran dalam memutus suatu perkara agar putusan yang dibuat bisa bermanfaat dan adil bagi para pelaku dan korban dan juga masyarakat luas. Dalam mempertimbangkan suatu putusan, hakim harus mempertimbangkan segala aspek yuridis dan seluruh fakta yang ada didalam suatu persidangan, disamping itu hakim juga harus mengetahui secara detail tentang perkara yang sedang ia tangani tersebut supaya hakin terhindari dari kesalahan dalam memutuskan sebuah hukuman.

Teori pendekatan yang bisa dijadikan dasar untuk mempertimbangkan suatu perkara guna menperoleh suatu putusan yang sifatnya adil dan bermanfaat bagi semua orang dimasa kini hingga masa depan yaitu hakim akan menggunakan beberapa teori seperti teori keseimbangan, pendekatan seni atau suatu intuisi, keilmuan, bahkan hakim juga akan belajar dari suatu pengalaman-pengalam yang ia dapatkan dari setiap persidangan, hakim juga menggunakan teori ratio decidendi yaitu penalaran yang dilakukan oleh hakim yang kemudian hal itu akan menjadi alasan pokok dari suatu putusan.

Dalam tindak pidana korupsi yang menjadi dasar pertimbangan Majelis Hakim dalam menjatuhkan sanksi pidana kurungan pengganti denda sebagai salah satu sanksi kumulatif dalam putusan suatu perkara yang sedang ditangani dengan pertimbangan secara yuridis dan melihat fakta-fakta hukum dalam persidangan. Dalam tindak pidana korupsi didalam persidangan seorang harus diperiksa dengan sangat teliti, untuk mengetahui apakah benar jika perbuatan yang ia lakukan merupakan suatu perbuatan korupsi, disamping seluruh bukti yang ditunjukkan dalam persidangan harus diperiksa dan bisa dijadikan pertimbangan oleh hakim untuk memutus perkara korupsi tersebut.

Majelis Hakim dalam tindak pidana korupsi akan mempertimbangkan setiap unsur ketentuan pidana yang dikdakwakan kepada terdakwa untuk mengetahui apakah unsur tersebut telah terpenuhi atau tidak dengan perbuatan yang dilakukan terdakwa. Majelis hakim juga akan mempertimbangkan fakta yang terjadi atau terungkap di persidangan berupa keterangan dari sejumlah saksi, ahli, maupun keterangan terdakwa hingga didapatkan suatu fakta hukum di muka persidangan yang akan sangat mempengaruhi dari pada putusan hakim tersebut.

Sebelum menjatuhkan putusan ada hal yang juga perlu dipertimbangkan oleh Majelis Hakim, yaitu hal-hal yang memberatkan dan meringankan dari diri dan perbuatan terdakwa. Hal-hal yang memberatkan yaitu perbuatan yang telah dilakukan terdakwa yang menyebabkan kerugikan negara dan meresahkan masyarakat. Sedangkan hal yang meringankan adalah sikap terdakwa di depan persidangan, latar belakang terdakwa apabila belum pernah dihukum. Keputusan hakim yang telah mempunyai kekuatan hukum tetap dan telah dilaksanakan, akan dijadikan sebagai dokumen yang dinamakan yurisprudensi. Dokumen ini banyak mengandung nilai-nilai hukum yang telah diperlukan dan bahkan tidak sedikit yang berlandaskan pada pertimbangan- pertimbangan kemanusiaan, agama, adat dan filsafat hukum.

\section{KESIMPULAN}


Berdasarkan hasil analisis di atas, maka dapat disimpulkan bahwa: 1) Pengaturan sanksi kumulatif dalam tindak pidana korupsi diatur dalam Pasal 2, Pasal 6, Pasal 8, Pasal 9, Pasal 10, Pasal 12, Pasal 12B Undang- Undang Nomor 20 Tahun 2001 tentang Perubahan atas Undang-Undang Nomor 31 Tahun 1999 tentang Pemberantasan Tindak Pidana Korupsi. Pengertian kumulatif adalah segala sesuatu yang sifatnya penggabungan, penumpukan, atau penambahan dari bagian-bagian, kumulatif juga berarti menimbun. Penjatuhan sanksi yang bersifat kumulatif adalah penjatuhan dua jenis sanksi pokok dalam hukum pidana yakni sanksi pidana penjara dan sanksi pidana denda. Undang- Undang Pemberantasan Tindak Pidana Korupsi merupakan undang- undang yang menganut sistem perumusan sanksi secara kumulatif. Penjatuhan sanksi dengan sifat kumulatif tidak memberikan alternative kepada terdakwa untuk memilih antara sanksi pidana penjara atau sanksi pidana denda akan tetapi dijatuhkan secara serentak, artinya terdakwa harus dijatuhi dengan dua sanksi pokok sekaligus. Perumusan sanksi kumulatif dalam tindak pidana korupsi memiliki ciri khusus yakni terdapat kata hubung "dan" dalam perumusan aturannya seperti bunyi dari pasal-pasal tersebut diatas. 2) Dasar pertimbangan hakim dalam menjatuhkan sanksi pidana kurungan pengganti denda sebagai suatu sanksi kumulatif dalam tindak pidana korupsi yaitu pertimbangan secara yuridis dan melihat fakta-fakta hukum yang terungkap di dalam persidangan. Untuk menjatuhkan sanksi dalam tindak pidana korupsi majelis hakim akan mempertimbangkan setiap unsur dalam pasal yang didakwakan kepada terdakwa dengan perbuatan yang dilakukan terdakwa untuk mengetahui apakah setiap unsur tersebut telah terpenuhi atau tidaknya, hakim juga mempertimbangkan keterangan saksi-saksi, keterangan ahli dan alat-alat bukti di dalam persidangan, selain itu hakim juga akan mempertimbangkan hal-hal yang memberatkan dan meringankan terdakwa. Pendekatan yang dipergunakan oleh hakim dalam pertimbangan penjatuhan putusan adalah teori keseimbangan, teori pendekatan seni dan intuisi, teori pendekatan keilmuan, teori pendekatan pengalaman dan teori ratio decidendi.

\section{DAFTAR PUSTAKA}

Arsyad, J. H. (2013). Korupsi dalam perspektif HAN (Hukum Administrasi Negara). Jakarta: Sinar Grafika. Aryadi, G., \& Pudyatmoko, Y. S. (2020). Penerapan Kumulasi Sanksi Eksternal dalam Penegakan Hukum Pidana Korupsi oleh Pejabat Pemerintahan di Kabupaten Sleman. Jurnal Ilmu Hukum, 4(2), 155-174.

Bauhr, M., Charron, N., \& Wängnerud, L. (2019). Exclusion or interests? Why females in elected office reduce petty and grand corruption. European Journal of Political Research, 58(4), 1043-1065. https://doi.org/10.1111/1475-6765.12300

Haryadi. (2014). Tinjauan Yuridis Perumusan Sanksi Pidana Bagi Pelaku Tindak Pidana Korupsi Menurut Undang-Undang No. 31 Tahun 1999 Jo. Undang-undang No. 20 Tahun 2001 Dalam Perspektif Tujuan Pemidanaan. Jurnal Ilmu Hukum Jambi, 5(1), 139-154.

Irfani, M., \& Maerani, I. A. (2019). Criminal Code Policy in The Effort of Corruption Prevention in Institutions Regional Disaster Management Agency. Jurnal Daulat Hukum, 2(1), 75-82.

Jurdi, F. (2019). Logika Hukum. Jakarta: Prenadamedia Group.

Kristian, \& Gunawan, Y. (2015). Tindak Pidana Korupsi. Bandung: Rafika Aditama.

Mertha, K. (2014). Efek Jera Pemiskinan Koruptor Dan Sanksi Pidana. Denpasar: Udayana University Press.

Valerian, D. (2019). Meretas Konsep Baru Pidana Denda Terhadap Tindak Pidana Korupsi. Jurnal Antikorupsi Integritas, 05(2), 87-116. https://doi.org/10.32697/INTEGRITAS.V5I2.445 